ROCZNIKI TEOLOGICZNE

Tom LXVI, zeszyt $10-2019$

DOI: http://dx.doi.org/10.18290/rt.2019.66.10-5

IRYNA PIESHA

TETIANA YABLONSKA

\title{
DEVELOPMENT OF THE STATE FAMILY POLICY, ORIENTED ON A WELL-FUNCTIONING FAMILY
}

A b s t r a c t: Introduction. The current trends of the family institution in Ukraine are examined in the context of the state family policy.

The purpose of the article is to analyze the trends of a modern family in Ukraine and to find ways to support it at the level of formation of the state family policy.

Research results. On the basis of the statistics data and scientific researches, the peculiarities of Ukrainian families, in particular, the crisis manifestations at their functioning (a high divorce rate, low birth rate, appearance of alternative forms of family unions) are analyzed. The data are analyzed revealing negative social phenomena that are consequences of family dysfunction: irresponsible parenting, domestic violence, social orphanhood, juvenile crime. It is argued that the state family policy focused on working with dysfunctional families does not actually support well-functioning families.

Conclusions. The article substantiates the necessity of a holistic family policy aimed at family development, supporting family well-functioning, promoting systematic, consistent work in the following main directions: formation of the family values priority in society; preparation of children and youth for family forming, development of responsible parenting; prevention of family dysfunction; assisting parents rearing children; social support for families in difficult living conditions.

Key words: family; family policy; dysfunctional family; well-functioning family; family functions.

\section{Translated by Anastasia Yablonska}

Iryna PIesha - PhD in Pedagogy, Director of the State Institute of Family and Youth Policy under Ministry of Youth and Sport of Ukraine; address for correspondence: Isaakyana str., 18: office, 105, Kyiv, Ukraine, 01135; e-mail: pesha_iv@ukr.net

Tetiana YablonsKa - Doctor of Psychology, Professor, Taras Shevchenko National University of Kyiv; address for correspondence: Volodymyrska str., 64/13, Kyiv, Ukraine, 01601; e-mail: t_yablonska@ukr.net 


\section{INTRODUCTION}

A family can be considered as a structural social unit, reflecting in its microclimate a general state of its social environment, all social contradictions, influences and corresponding significant transformations. A family accumulates all social relations totally - social, national, political, economic, cultural, so that children from birth are involved in these relationships, which ensures socialization. Each family should be considered as a society subsystem, dependent on social-economic conditions and state policies as for families and children, and each family may react to external social problems by breach of internal ties that have been formed over the decades and passed on from generation to generation in the form of family traditions.

Rapid social-political changes in Ukraine have led to transformations of the family institution, accompanied by complications in fulfilment by a family of its functions, first of all, the educational ones, as well as by wide-spread occurrence of deviant parenthood, deviant behaviour of children and young people, and domestic violence. In such conditions, the need for a well-defined and coherent family policy aimed at family support in today's social-political environment and preventing negative phenomena is growing.

The performed analysis of the implemented state programs, researches on modern family development in Ukraine, and the activities of non-governmental organizations in the field of family assistance have led us to the conclusion that the ideas on family development are conceptualized on several levels: in state social policies, scientific theories and social practice, ${ }^{1}$ but, unfortunately, Ukraine does not have a consistent state policy as for families.

Ukraine has approved the Concept of the State Family Policy, which recognizes a family as an integral indicator of social development, reflecting the moral state of society and its demographic potential. The main principles of the state family policy are: sovereignty and autonomy of a family in its decision-making regarding its development; the differentiated approach to state guarantees provided for family social protection; parity equality and partnership between women and men in all spheres of life; social partnership of a family and the state built on the basis of responsibility for a family shared between parents, children, other family members and the state; the priority of each child's interests, regardless of his/her family; the continuity of generations, ensured by the transfer of national and cultural achievements,

1 T.F. Alekseenko, Kontseptualni ideyi ta modeli simeynoyi polityki: dosvid i shlyahy optimizatsiyi, Simeyna politika v Ukrayini: problemy i perspektyvy rozvytku: materialy Vseukrayinskoyi naukovo-praktichnoyi konferentsiyi (04 kvitnya 2018 r., m. Kiyiv) / [Red. kol. I.G. Gubeladze ta in.], Kyiv 2018, http://lib.iitta.gov.ua/710608/ (accessed: 20.08.2019). 
traditions, and customs to family descendants. ${ }^{2}$ At the same time, according to experts, many questions have been put forward regarding practical implementation of these main provisions as well as other state documents formulating the family policy in Ukraine, in particular as for development of specific mechanisms for their implementation, as well as increased responsibility for their implementation. ${ }^{3}$

Modern studies of trends and problems of family development are performed in various fields, in particular: the problems of child guardianship organization, domestic violence elimination, foster family support and improvement of the social services quality, parental competence are studied in the social-pedagogical field (G.M. Bevz, ${ }^{4}$ N.M. Komarova, ${ }^{5}$ A.Y. Kapska \& I.V. Piesha, ${ }^{6}$ I.D. Zvereva $\&$ G.M.Laktionova ${ }^{7}$ ), as well as the problems of school-age children's and adolest cents' socialization in their interactions with families and school (T. Kravchene $\mathrm{ko}^{8}$ ), features of modern family education (T.F. Alekseenko ${ }^{9}$ ) and others. The psychological direction of researches is presented by studying of psychological characteristics of family interactions and children upbringing (T.M. Yablont ska, ${ }^{10}$ N.N. Bulatevich ${ }^{11}$ and others), psychological foundations and means of

${ }^{2}$ Kontseptsiya Derzhavnoyi simeynoyi polityki (vid 17 veresnya 1999 roku N 1063-XIV), Verhovna Rada Ukrayiny. Tekst pravovogo aktuiz zminamy ta dopovnennyamy stanom na zhovten 2010 r., s. 1, http://zakon1.rada.gov.ua/cgi-bin/laws/main.cgi?nreg=1063-14 (accessed: 21.08.2019).

${ }^{3}$ T.F. Alekseenko, Kontseptualni ideyi ta modeli simeynoyi polityki: dosvid i shlyahy optimizatsiyi, http://lib.iitta.gov.ua/710608/ (accessed: 21.08.2019).

${ }^{4}$ G.M. Bevz, Priyomna sim’ya: sotsialno-psihologichni vimiry, Kyiv: Vyd. Dim «Slovo» 2010.

5 Praktyki nadannya sotsialnyh poslug sim'yam, yaki perebuvayut u skladnyh zhittevyh obstavynah: naukovo-metodychniy zbirnik / za red. Komarovoyi NM. Derzh. In.-t. simeynoyi ta molodizhnoyi polityki, Kiyivskiy miskiy tsentr sotsialnyh sluzhb dlya sim'yi, ditey ta molodi, Kyiv 2016.

${ }^{6}$ AY. KAPSKa, I.V. PIESHa, Sotsialniy suprovid riznih kategoriy simey ta ditey, Kyiv: Tsentr navchalnoyi literatury 2012.

${ }^{7}$ Batkivstvo v radist': treningoviy kurs z formuvannya batkivskoyi kompetentnosti / Programa „Rodyna dlya dytyny” v Ukrayini; Institut pedagogichnoyi osvity i osvity doroslyh APN Ukrayiny; Derzhavna sotsialna sluzhba dlya sim'yi, ditey ta molodi; Derzhavniy In-t rozvytku sim'yi ta molodi / G.M. Laktionova (avt.-uporyad.), I.D. Zvereva (avt.-uporyad.). Vyd. 2-ge, perer. i dop., Kyiv: Feniks 2009.

${ }^{8}$ T. KravchenKo, Osnovni pidhody do organizatiyi vzaemodiyi sim'yi ta shkoly yak faktora sotsializatsiyi ditey shkilnogo viku, „Psihologo-pedagogichni problemy silskoyi shkoly” 2013, nr 47, s. 136-142, http://nbuv.gov.ua/UJRN/Ppps_2013_47_23 (accessed: 21.08.2019).

9 T.F. Alekseenko, Simeyne vyhovannya: kontseptualizatsiya idey teoriyi i praktyki, KyivUman: FOP Zhovtiy O.O. 2016.

${ }^{10}$ T.M. YablonsKa, Rozvytok identichnosti dytyny v systemi simeynyh vzaemyn, Sumy: Vydvo SumDPU im. A.S.Makarenka 2013.

11 N.N. Bulatevich, Perinatal Psychology: Formation History and Present, „Fundamental and Applied Researches In Practice of Leading Scientific Schools” 2015, 4(10), s. 3-11, http:// fund-issled-intern.esrae.ru/pdf/2015/4\%20(10/188.pdf (accessed: 21.08.2019). 
psychological correction of a family as a child's development environment (N.Yu. Maksimova, ${ }^{12}$ Z.G. Kisarchuk ${ }^{13}$ and others). At the same time, despite significant advances made by national scientists and practitioners, a coherent state policy as for families that could consistently implement the proposed approaches and practices has not been developed yet.

The purpose of the article is an attempt to answer the following questions:

What are the main developmental trends and difficulties of a modern Ukrainian family?

What solutions for the determined trends and difficulties of modern Ukrainian families can be proposed in developing of the state family policy?

\section{RESEARCH METHODS}

The research was carried out on the basis of analysis and generalization of statistical data, sociological, psychological and pedagogical studies of problems and trends in family and family policy development in Ukraine and Poland.

\section{RESEARCH RESULTS}

According to the statistical data and research results, Ukraine, like many developed countries, is experiencing a crisis of the family institution; this fact is reflected by a number of unfavourable indicators of family functioning.

Instability of marriage relations. Ukraine belongs to the group of European countries showing a high divorce rate. There is a high probability of marriage breakdown at all its stages. So, nearly one in ten young Ukrainians at the age even of 25-34 have a negative experience of marital life, are divorced. In 2015, $11 \%$ of marriages of young men and $15 \%$ of marriages of young women were, in fact, remarriage. The main reason for divorce is the tensions in marital relations, first of all, the moral and psychological, emotional aspects of relationships (conflict of interest, alienation), aggravated by the unresolved material and housing

12 N.Yu. Maksimova, Tipologiya simey, yaki potrebuyut sotsialno-psyhologichnoyi dopomogy, Visnyk Kiyivskogo natsionalnogo universitetu imeni Tarasa Shevchenka. Psyhologiya. Pedagogił ka. Sotsialna robota, Kyiv: Wydawnycnwo Kiyivskogo natsionalnogo universitetu imeni Tarasa Shevchenka 2017, t. I, s. 45-51.

13 Psyhologichna dopomoga sim'yi: navchalniy posibnyk (u 3 knigah). Za zag. red. Z.G. Kisarchuk, Kyiv: Glavnik 2006. 
problems. ${ }^{14}$ At the same time, half of the broken couples have common children; accordingly, the number of single-parent families and children living with one parent, most often with their mothers, is constantly increasing.

Occurrence of alternative forms of family unions, in particular unregistered marriages: in $2015,47 \%$ of young people felt positive as for unregistered marriages, $23 \%$ of them considered such family forms "possible but not for themselves"; $18 \%$ of the respondents had a negative attitude towards this phenomenon, and $3 \%$ of the polled believed unregistered marriages were immoral. ${ }^{15}$ According to sociologists, we are talking about significant changes in family life of people, when cohabitation before or without marriage, births of children of unwed parents become a significant competition to traditional marriages. In Ukraine, as in most other countries, there is a transformation of mass consciousness in relation to an officially registered marriage, which ceases to be the only possible form of joint living of partners. ${ }^{16}$

Low birth rate: despite the birth rate increase in 2006-2010, Ukraine belongs to the group of countries with a low fertility rate. The total fertility rate in 2015 was 1.51 children per woman (excluding data from the temporarily occupied territory of Crimea and Sevastopol and on Donetsk and Luhansk regions). According to demographers, the existing fertility rate does not support even a simple reproduction of the population; the total fertility rate for the simple reproduction should be 2.1-2.2 children per woman of the reproductive age. ${ }^{17}$

Births of children by unmarried women. Today in Ukraine, every fifth child (20.6\% of total deliveries in 2015, including $19.5 \%$ in urban settlements and $22.6 \%$ in rural areas) is born by an officially unmarried mother. In 2015, the number of children born by unmarried mothers was almost 84.8 thousand persons. ${ }^{18}$ Despite

${ }^{14}$ Tsinnisni orientatsii suchasnoyi ukrayinskoyi molodi, Schorichna dopovid Prezidentu Ukrayiny, Verhovniy Radi Ukrayiny pro stanovysche molodi v Ukrayini (za pidsumkami 2015 roku) / Derzh. In-t simeynoyi ta molodizhnoyi polityky; [red. kol.: I.O. Zhdanov, gol. red. koleg., O.Y. Yarema, I.I. Belyaeva ta in.], Kyiv 2016.

15 Ibid.

16 T.V. Medina, Osoblyvosti transformatsiyi institutu shlyubu v Ukrayini. Simeyna polityka v Ukrayini: problemy i perspektyvy rozvytku: materialy Vseukrayinskoyi naukovo-praktichnoyi konferentsiyi (04 kvitnya 2018 r., Kiyiv). [Red. kol. I. G.Gubeladze ta in.], Kyiv 2018, s. 96-100, http://lib.iitta.gov.ua/710608/ (accessed: 21.08.2019).

17 Bezpeka dytyny $v$ informatsiyno-komunikatsiynomu prostori. Schorichna derzhavna dopovid pro stanovysche ditey v Ukrayiini za pidsumkamy 2016 roku Derzh. In.-t simeynoyi ta molodizhnoyi polityki, Kyiv 2017, https://dismp.gov.ua/downloads/bezpeka-ditini-vinformacijno-komunikacijnomu-prostori-shhorichnoyi-derzhavnoyi-dopovidi-pro-stanovishheditej-v-ukrayini-za-pidsumkami-2016-roku (accessed: 21.08.2019).

18 Ibid. 
the fact that society's attitude toward extramarital children has become more tolerant, at the same time, such families experience significant economic and psychological difficulties, which makes them vulnerable concerning well-being and favourable conditions of children's development.

These determined tendencies, as well as the social and economic problems encountered by Ukrainian families at the present stage of social life, affect family normal life, cause transformations or violations of its functions.

Family functions are the basis of family life, providing fulfilment of the essential needs of each family member, of a family as a group, as well as the most important social demands. Family functions correlate with the life of society as a whole, and, accordingly, vary depending on the state of society, the level of social needs and requirements. The main family functions are sexual, reproductive, educational, economic and socializing. ${ }^{19}$ From the point of view of social significance, the educational family function occupies a special place. In comparison with other functions, it has a cross-cutting nature and is associated with virtually every other function, since the transfer of social norms, values and experience touches all spheres of both family and society.

In the case of difficult life circumstances that a family cannot overcome without third-party assistance certain functions are fulfilled in an improper manner, which in turn affects the vital needs of family members. Social phenomena testifying to family dysfunction are social orphanhood, children's homelessness or neglect, juvenile crimes, alcoholism and drug addiction, child prostitution. All these negative manifestations are the result of improper fulfilment by a family, as a social institution, of its main function, namely: children rearing and future generation value formation.

Dysfunctional families manifest the following social phenomena.

Orphaned children and children deprived of parental care. At the end of 2015, there were 73,182 children in Ukraine who had the social status of an orphaned child or a child deprived of parental care, only $27.9 \%$ of which were real orphans. The share of orphan children in relation to the total number of children in Ukraine was $0.96 \%{ }^{20}$

Irresponsible parenthood, termination of parental rights. Thus, the sad statistics show that the majority of children sent to temporary accommodation

${ }^{19}$ Entsiklopediya dlya fahivtsiv sotsialnoyi sfery. Za zag. red. prof. I.D.Zverevoyi. Kiyiv, Simferopol: Universum 2012.

${ }^{20}$ Bezpeka dytyny v informatsiyno-komunikatsiynomu prostori, https://dismp.gov.ua/downloads/ bezpeka-ditini-v-informacijno-komunikacijnomu-prostori-shhorichnoyi-derzhavnoyi-dopovidipro-stanovishhe-ditej-v-ukrayini-za-pidsumkami-2016-roku (accessed: 21.08.2019). 
establishments in 2015 (shelters for children and centres for social and psychological rehabilitation of children) had a family: $55 \%$ of the children had an incomplete family, $25 \%$ had a full one. $73.6 \%$ of the children in the centres of social and psychological rehabilitation got into them due to difficult life circumstances. ${ }^{21}$

During 2015, 10345 cases of parental rights termination were sent to the first instance courts, 10239 cases were heard, and of which 8448 cases were filed with satisfaction. ${ }^{22}$ This data characterizes the scale of the important problem - irresponsible parenthood, which can lead to social orphanhood of children.

Domestic violence. As for domestic violence prevention, during 2014, 119 977 appeals were filed on domestic violence (702 appeals concerning children, 108037 appeals from women, 11288 appeals from men). The number of identified children affected by various forms of violence in 2015 was 1065 people. ${ }^{23}$

Juvenile criminality. In 2015, 5725 juveniles committed criminal offenses. The overwhelming majority of crimes were committed for the purpose of taking possession of someone else's property: $63.7 \%$ of minors committed theft. During this year, 4589 juveniles were convicted for committed crimes. At the beginning of 2016, there were almost 2.5 thousand juvenile offenders and minors under custody, according to the State Penitentiary Service of Ukraine. ${ }^{24}$

However, despite the obvious signs of the family institution crisis, the value of a family and trust in it in the public consciousness of Ukrainians still remain steadily high. A family, family relations, according to polls, is one of the most important vital values of Ukrainian youth. In 2015, matrimonial behaviour of young people of Ukraine was characterized by a high level of marriages: almost $80 \%$ of men and $85 \%$ of women who registered marriage were persons under the age of 35 years. As for the first marriages, these figures exceeded $90 \%{ }^{25}$

According to the sociological monitoring performed the Institute of Sociology of the National Academy of Sciences of Ukraine in 1994-2014, the value of a family, family life and well-being of children was dominant in 2009, 2012 and

21 Ibid.

${ }^{22}$ Zahyst ditey, yaki potrebuyut osoblivoyi uvagi suspilstva. Statistichniy zbirnyk. Derzhavna sluzhba statystiki Ukrayini, 2016, http://www.ukrstat.gov.ua/druk/publicat/kat_u/publzahist_u. htm (accessed: 21.08.2019).

23 Ibid.

24 Bezpeka dytyny v informatsiyno-komunikatsiynomu prostori, https://dismp.gov.ua/downloads/ bezpeka-ditini-v-informacijno-komunikacijnomu-prostori-shhorichnoyi-derzhavnoyi-dopovidipro-stanovishhe-ditej-v-ukrayini-za-pidsumkami-2016-roku (accessed: 21.08.2019).

${ }^{25}$ Tsinnisni orientatsii suchasnoyi ukrayinskoyi molodi. 
$2014 .{ }^{26}$ This trend was preserved also in 2017: the results of the "Youth of Ukraine - 2017" survey showed that a family, family relationships remain a major value for youth (64\% of respondents), it is higher than such values as "health" (54\%) and "career" $(39 \%){ }^{27}$ The goal of family creation for young people is, first of all, children birth and rearing (77\%) and love and the desire to live with a close friend (81\%), in contrast to the more pragmatic approach - "improvement of the material situation" (12\%) and "joint household management" $(29 \%){ }^{28}$

The family life values are understood as a complex, integrated formation, determining a stable positive motivation for family creating (marriage), actualization of knowledge, social skills and competence necessary for family function fulfilment, development of personal qualities of a family person, the ability to understand empathically a partner and to behave constructively in relationships. The marital life values include the value of marriage as a form of family organization, the desire for child birth and rearing in a formal marriage, trust and love, mutual respect and mutual understanding in a family. ${ }^{29}$

At the same time, in contrast to the high trust into the family institution in society, Ukraine does not have a coherent and consistent state family policy, namely:

- at the level of the executive power, a state body, forming and implementing the state family policy, and not the social security policy, has not been defined yet;

- there are no effective mechanisms forming the responsibilities of local executive bodies and local self-government bodies concerning family situations;

- insufficient development of the social service system for families, its inconsistency with the current $\mathrm{s}$ needs of the population;

- imperfect mechanisms forming responsible and informed paternity, lack of understanding at the state level of the need for their implementation;

- lack of a coherent system for monitoring and assessing the needs of Ukrainian families and opportunities to receive an adequate social support.

The support of the family institution, family values and responsible parenting is the tasks of the state family policy as an integral part of the state social policy of Ukraine. The subordination of the social work with families to the Ministry of Social Policy of Ukraine, made in 2010, was aimed at combining all components

26 Ibid.

27 Molod' Ukrayiny - 2017. Rezultaty sotsiologichnogo doslidzhennya, Ternopil: TOV «Terno-graf» 2017, s. 7, http://www.dsmsu.gov.ua/media/2017/11/16/7/Socdoslidjennya_2017.pdf (accessed: 21.08.2019).

28 Molod Ukrayiny - 2015. Rezultaty sotsiologichnogo doslidzhennya, GFKUkraine, Kyiv 2015, http://dsmsu.gov.ua/media/2015/12/09/5/Molod_Ukraine_block.pdf (accessed: 21.08.2019).

29 Tsinnisni orientatsii suchasnoyi ukrayinskoyi molodi. 
of the family policy under the management of a single executive body. But such unification has not lead to the expected result - the coordination of material and social support at work with families. The transfer of state family policy functions to the Ministry of Social Policy of Ukraine has led to the identification of the family policy with the social one.

At present, various departments of the Ministry of Social Policy regulate social benefits, social work and state program implementation concerning work with families. But none of the departments coordinates this activity to obtain a joint result. The questions which state body shall prevent family disadvantages, in particular, shall promote family values in society, preparing young people for family life, forming responsible parenthood, etc. remains open still.

One of the main tasks of the state social policy is its supports of socially disadvantaged categories. At the same time, at the state level, there is no ideology of the family life value as the basis of a healthy society. As a result, a state vision of the state family policy priorities is absent:

- preparation of children and young people for family life is made sporadically, at the level of individual projects and activities;

- a holistic state system of social support for families with children is not formed, it is aimed primarily at the prevention of family disadvantages;

- the present state system of family support forms a consumer's attitude towards state assistance, does not contribute to development of parents' responsibility for their own lives and their children.

In the context of the current demands on an effective system of the state administration, it is necessary to differentiate between the tasks and directions of the family and social policies of Ukraine, first and foremost, to the outline the subject area of the family policy. ${ }^{30}$ The state should create such family polt icy that is adapted to changing living conditions and urgent needs of modern Ukrainian families. Taking into account these peculiarities, system monitoring of the situation with families in Ukraine should become the basis for an effective state family policy.

At present, the Ministry of Social Policy works exclusively with the consequences of family disadvantages and irresponsible paternity and does not consider the support of well-functioning families as a priority for its activities. Implementation of the family-value ideology in the state social policy, formation

30 O.M. Kulyк, Sfera derzhavnoyi simeynoyi politiki v Ukrayini: sutnist i problemy, Derzhavne budivnytstvo 2013, nr 2, www.kbuapa.kharkov.ua/e-book/db/2013-2/doc/5/03.pdf (accessed: 21.08.2019). 
of a comprehensive system of the state family policy, first of all, requires determination of a state executive body that will develop and implement policies supporting family well-functioning. Such body should be created due to, firstly, the impossibility to implement the family policy by means of branch management; secondly, the need for coordinated actions of central and local executive authorities and local self-government bodies; thirdly, the need to involve civil society institutions.

Such a change in the family policy priorities will promote systematic, consistent work in four main areas.

I. Formation of the family value priority in society, which includes:

- formation and implementation of a state information policy aimed at promoting a family as the highest value in society;

- creation and performance of social advertising as an effective mechanism influencing value orientations of children and young people.

II. Preparation of children and youth for family founding, formation of responsible parenting through:

- introduction of educational programs promoting family relationships values among children (educational programs in kindergartens, schools, clubs at the place of living, etc.);

- preparation of young couples for family life that requires development and implementation of educational and informational materials, a network of training centres for young people and newly married young couples; creation of advisory services, hot lines for young people on marital life, family relationships, sexual life, etc.

III. Prevention of family disadvantages; assistance to parents raising children:

- assistance to parents in establishing of good family relationships, raising children: counselling, training, parenting clubs at their place of living;

- dissemination of information materials, television and radio programs related to establishment of family relationships, children rearing, age crises, relationships with adolescents, etc.

IV. Social support for families in difficult living conditions through introduction:

- support and assistance for families with children with special needs (children with disabilities, HIV-infected children), as well as children with antisocial behaviour: specialized centres providing assistance according to a child's probe lems; social support for different categories of families and children; system of material and social support for families raising children with special needs;

- the system of state control over families with parents not properly fulfilling their parental responsibilities; 
- improvement of the social assistance system for families in difficult living conditions: a combination of material and social support, establishment of an institutional system for the benefit of such families, children from such families, etc.;

- introduction of mechanisms for bringing to justice the parents not properly performing parental responsibilities.

Therefore, the priority task of the state family policy in Ukraine should be preventive work aimed at forming responsible parenting, prevention of family disadvantage, and preventing children from leaving their families. The state family policy should form a "fashion" for a full family with several children, personal and social value orientations for family and family life; should provide conditions for autonomous self-sufficient functioning of families for births, proper provision and upbringing of the desirable and socially necessary number of children. ${ }^{31}$

The significance of the family institute support and development is confirmed by the majority of national scientists who consider it necessary to take specific steps to strengthen the family institution, taking into account the latest trends in this area, using successful foreign experience in family supporting and developing. Such steps include, in particular: development of a family policy strategy in Ukraine; organization of wide-range discussion and practical implementation of the issues that will be relevant during the next years as for the family institution, with attraction of psychologists, teachers, social workers, businessmen, doctors, journalists, representatives of religious and non-governmental organizations; increased attention of the scientific community to researches of various aspects concerning family issues; introduction of educational programs describing families, the culture of family communications and family traditions in educational institutions in order to form the family values of the younger generation; introduction of wide educational projects; study of international experience of effective family policies and implementation of the best practices by taking into account the realities of Ukrainian society; cooperation between state and non-governmental organizations; support of the volunteer movement in the field of social work with families. ${ }^{32}$

31

Stanovysche simey v Ukrayini (za pidsumkamy 2010-2013 rokiv): Schorichna derzhavna dopovid Prezydentovi Ukrayiny, Verhovniy Radi Ukrayiny, Kabinetu Ministriv Ukrayiny pro stanovysche simey i stan realizatsiyi derzhavnoyi simeynoyi polityki / Ministerstvo sotsialnoyi polityki Ukrayiny, Derzhavniy Instytut simeynoyi ta molodizhnoyi polityki, Kyiv 2014.

${ }^{32}$ Simeyna polityka v Ukrayini: problemy i perspektyvy rozvytku: materialy Vseukrayinskoyi naukovo-praktichnoyi konferentsiyi (04 kvitnya 2018 r., Kyiv) [Red. kol. I. G. Gubeladze ta In.], Kyiv 2018. http://lib.iitta.gov.ua/710608/ (accessed: 21.08.2019). 


\section{DISCUSSION}

As it is well-known, many European countries suffer similar transformations of their family institutions, in particular similar trends are observed in Poland (T. Kopciał, ${ }^{33}$ I. Pospiszyl ${ }^{34}$ and others). Polish scholars and practitioners are studying actively the features of a modern family, its problems, are developing measures for family support and development (J. Chwaszcz, J. Gorbaniuk ${ }^{35}$ and others) and are involved in prevention in the field of development and education of children and youth (M. Deptuła, A. Potorska, S. Borsich). ${ }^{36}$

The Poland's family policy can also serve as an example of effective care for families at the state level. ${ }^{37}$ Thus, in 1990-1997, the state's family-related actions were directed primarily to families in difficult financial situations, and the family policy was mainly focused on finding money in the state budget in order to respond to the most important needs of such families. The family policy concept adopted in 1997 was the first integrated governmental policy as for families. It covered the following areas: conditions for family economic function implementation, family living conditions, conditions for children guardianship, conditions for the educational and cultural family functions, family legal protection, support of family health, and help for families with legally incapable members or ones with dysfunctional threats. The developed family policy took into account its difference from the social policy: the social policy is targeted and aimed at dysfunctional families, but the family policy is oriented to families who do not need social assistance. This made possible to formulate the clear family policy goals in Poland, many of which have a developmental and educational orientation. Based on understanding of the family policy as the most important element of the country's stable development and best investment, Poland consistently improves family policy both at the level of strategic goals and at the level of specific steps for family support and development.

33 T. Kopciat, Wybrane przyczyny dysfunkcjonalności rodziny, „Roczniki Teologiczne” 62(2015), z. 10, DOI: http://dx.doi.org/10.18290/rt.2015.62.10-6 (accessed: 21.08.2019).

34 I. Pospiszyl, Patologie społeczne, Warszawa: Wydawnictwo Naukowe PWN 2008.

35 J. Chwaszcz, J. Gorbaniuk, Family growth supporting resources, Lublin: Natanaelum Association Institute for Psychoprevention and Psychotherapy 2015, http://www.ipip.info.pl/pl/ monografie/19-family-growth-supporting-resources (accessed: 21.08.2019).

${ }^{36}$ M. DeptuŁa, A. Potorska, S. Borsich, Wczesna profilaktyka problemów w rozwoju psychospołecznym i zachowań ryzykownych dzieci i młodzieży, Warszawa: PWN 2018.

${ }^{37}$ G. Kryshtal, Simeyna polityka v ES - pryklad Polschi, http://do.gendocs.ru/docs/index29699. html (accessed: 21.08.2019). 


\section{CONCLUSIONS}

Thus, the main current family trends in Ukraine is the change in the forms and structures of marital relations; a reduced number of children; instable marriage; an increase number of single-parent families and families in difficult living conditions; disorganization of its main functions, in particular, educational and socializing. At the same time, for many years, the state directs the main moral and material resources in support of problematic (dysfunctional) families, focusing on overcoming the consequences of family disadvantages. At the same time, in practice, attention is not given to conditions for development of well-functioning full families with children and for increase of the family institution prestige in society.

The predominant family policy orientation on support of socially vulnerable and dysfunctional families is hampering formation of a nationwide system supporting a family as a social institution. Therefore, there is an urgent need to form a holistic state family policy by introducing a policy supporting family well-functioning as a priority. Such a change in the family policy priorities will promote systematic, consistent work in the main directions: family value formation in society; preparation of children and youth for family founding, for responsible parenting; prevention of family dysfunction; assisting to parents rearing children; social support for families in difficult living conditions.

To develop and implement an effective family policy, it is necessary to expand state interactions with public organizations, to study the international experience of effective family policy and to implement the best practices supporting and developing the family institution.

\section{BIBLIOGRAPHY}

Alekseenko T.F., Kontseptualni ideyi ta modeli simeynoyi polityki: dosvid i shlyahy optimizatsiyi, Simeyna politika v Ukrayini: problemy i perspektyvy rozvytku: materialy Vseukrayinskoyi naukovo-praktichnoyi konferentsiyi (04 kvitnya 2018 r., m. Kiyiv) / [Red. kol. I.G. Gubeladze ta in.], Kyiv 2018, http://lib.iitta.gov.ua/710608/ (accessed: 21.08.2019).

Alekseenko T.F., Simeyne vyhovannya: kontseptualizatsiya idey teoriyi i praktyki, Kyiv-Uman: FOP Zhovtiy O.O. 2016.

Batkivstvo v radist: treningoviy kurs z formuvannya batkivskoyi kompetentnosti / Programa „Rodyna dlya dytyny” v Ukrayini; Institut pedagogichnoyi osvity i osvity doroslyh APN Ukrayiny ; Derzhavna sotsialna sluzhba dlya sim'yi, ditey ta molodi ; Derzhavniy In-t rozvytku sim'yi ta molodi / G.M. Laktionova (avt.-uporyad.), I.D. Zvereva (avt.-uporyad.). Vyd. 2-ge, perer. i dop. Kyiv: Feniks 2009.

Bevz G.M., Priyomna sim'ya: sotsialno-psihologichni vimiry, Kyiv: Vyd. Dim «Slovo» 2010.

Bezpeka dytyny $\mathrm{v}$ informatsiyno-komunikatsiynomu prostori. Schorichna derzhavna dopovid pro stanovysche ditey v Ukrayiini za pidsumkamy 2016 rokию Derzh. In.-t simeynoyi ta 
molodizhnoyi polityki, Kyiv 2017, https:/dismp.gov.ua/downloads/bezpeka-ditini-v-informacijno-komunikacijnomu-prostori-shhorichnoyi-derzhavnoyi-dopovidi-pro-stanovishhe-ditej-v-ukrayini-za-pidsumkami-2016-roku (accessed: 21.08.2019).

Bulatevich N.N., Perinatal Psychology: Formation History and Present, „Fundamental and Applied Researches In Practice of Leading Scientific Schools" 2015, 4 (10), s. 3-11, http:// fund-issled-intern.esrae.ru/pdf/2015/4\%20(10/188.pdf (accessed: 21.08.2019).

Chwaszcz J., Gorbaniuk J., Family growth supporting resources, Lublin: Natanaelum Association Institute for Psychoprevention and Psychotherapy 2015, http://www.ipip.info.pl/pl/monografie/19-family-growth-supporting-resources (accessed: 21.08.2019).

DeptuŁa M., Potorska A., Borsich S., Wczesna profilaktyka problemów w rozwoju psychospołecznym i zachowań ryzykownych dzieci i miodzieży, Warszawa: PWN 2018.

Entsiklopediya dlya fahivtsiv sotsialnoyi sfery. Za zag. red. prof. I.D.Zverevoyi, Kiyiv-Simferopol: Universum 2012.

Kapska A.Y., Piesha I.V., Sotsialniy suprovid riznih kategoriy simey ta ditey, Kyiv: Tsentr navchalnoyi literatury 2012.

Kontseptsiya Derzhavnoyi simeynoyi polityki (vid 17 veresnya 1999 roku N 1063-XIV), Verhovna Rada Ukrayiny. Tekst pravovogo aktuiz zminamy ta dopovnennyamy stanom na zhovten 2010 r., s. 1, http://zakon1.rada.gov.ua/cgi-bin/laws/main.cgi?nreg=1063-14 (accessed: 21.08.2019).

KopciaŁ T., Wybrane przyczyny dysfunkcjonalności rodziny, „Roczniki Teologiczne” 62(2015), z 10, DOI: http://dx.doi.org/10.18290/rt.2015.62.10-6 (accessed: 21.08.2019).

KravChEnKo T., Osnovni pidhody do organizatiyi vzaemodiyi sim'yi ta shkoly yak faktora sotsializatsiyi ditey shkilnogo viku, „Psihologo-pedagogichni problemy silskoyi shkoly” 2013, nr 47, s. 136-142, http://nbuv.gov.ua/UJRN/Ppps_2013_47_23 (accessed: 21.08.2019).

Kryshtal G., Simeyna polityka v ES - pryklad Polschi. http://do.gendocs.ru/docs/index-29699. html (accessed: 21.08.2019).

KuLyк O.M., Sfera derzhavnoyi simeynoyi politiki v Ukrayini: sutnist i problemy. Derzhavne budivnytstvo, 2013, nr 2, www.kbuapa.kharkov.ua/e-book/db/2013-2/doc/5/03.pdf (accessed: 21.08.2019).

Maksimova N.Yu., Tipologiya simey, yaki potrebuyut sotsialno-psyhologichnoyi dopomogy. Visnyk Kiyivskogo natsionalnogo universitetu imeni Tarasa Shevchenka. Psyhologiya. Pedagogika. Sotsialna robota, Kyiv: Wydawnycnwo Kiyivskogo natsionalnogo universitetu imeni Tarasa Shevchenka 2017, t. I, s. 45-51.

Medina T.V. Osoblyvosti transformatsiyi institutu shlyubu v Ukrayini. Simeyna polityka v Ukrayini: problemy i perspektyvy rozvytku: materialy Vseukrayinskoyi naukovo-praktichnoyi konferentsiyi (04 kvitnya 2018 r., Kiyiv). [Red. kol. I. G.Gubeladze ta in.], Kyiv 2018, s. 96100, http://lib.iitta.gov.ua/710608/ (accessed: 21.08.2019).

Molod Ukrayiny - 2017. Rezultaty sotsiologichnogo doslidzhennya, Ternopil: TOV «Terno-graf» 2017, s. 7, http://www.dsmsu.gov.ua/media/2017/11/16/7/ Socdoslidjennya_2017.pdf (accessed: 21.08.2019).

Molod' Ukrayiny - 2015. Rezultaty sotsiologichnogo doslidzhennya. GFKUkraine, Kyiv 2015, http://dsmsu.gov.ua/media/2015/12/09/5/Molod_Ukraine_block.pdf (accessed: 21.08.2019).

Pospiszyl I., Patologie społeczne, Warszawa: Wydawnictwo Naukowe PWN 2008.

Praktyki nadannya sotsialnyh poslug sim'yam, yaki perebuvayut u skladnyh zhittevyh obstavynah: naukovo-metodychniy zbirnik / za red. KomarovoYi N.M. Derzh. In.-t. simeynoyi ta molodizhnoyi polityki, Kiyivskiy miskiy tsentr sotsialnyh sluzhb dlya sim'yi, ditey ta molodi, Kyiv 2016.

Psyhologichna dopomoga sim'yi: navchalniy posibnyk (u 3 knigah) Za zag. red. Z.G. Kisarchuk, Kyiv: Glavnik 2006.

Stanovysche simey v Ukrayini (za pidsumkamy 2010-2013 rokiv): Schorichna derzhavna dopovid Prezydentovi Ukrayiny, Verhovniy Radi Ukrayiny, Kabinetu Ministriv Ukrayiny 
pro stanovysche simey i stan realizatsiyi derzhavnoyi simeynoyi polityki / Ministerstvo sotsialnoyi polityki Ukrayiny, Derzhavniy Instytut simeynoyi ta molodizhnoyi polityki, Kyiv 2014, https://dismp.gov.ua/files/dopovid-simya10-13-ebook.pdf (accessed: 21.08.2019). Simeyna polityka v Ukrayini: problemy i perspektyvy rozvytku: materialy Vseukrayinskoyi naukovo-praktichnoyi konferentsiyi (04 kvitnya 2018 r., Kyiv) [Red. kol. I.G. Gubeladze ta in.], Kyiv 2018, http://lib.iitta.gov.ua/710608/ (accessed: 21.08.2019).

Tsinnisni orientatsii suchasnoyi ukrayinskoyi molodi. Schorichna dopovid Prezidentu Ukrayiny, Verhovniy Radi Ukrayiny pro stanovysche molodi v Ukrayini (za pidsumkami 2015 roku) / Derzh. In-t simeynoyi ta molodizhnoyi polityky; [red. kol.: I.O. Zhdanov, gol. red. koleg., O.Y. Yarema, I.I. Belyaeva ta in.], Kyiv 2016.

YablonsKa T.M., Rozvytok identichnosti dytyny v systemi simeynyh vzaemyn. Sumy: Vyd-vo SumDPU im. A.S.Makarenka 2013.

Zahyst ditey, yaki potrebuyut osoblivoyi uvagi suspilstva. Statistichniy zbirnyk / Derzhavna sluzhba statystiki Ukrayini 2016. http://www.ukrstat.gov.ua/druk/publicat/kat_u/publzahist_u. htm (accessed: 21.08.2019).

\section{ROZWÓJ PAŃSTWOWEJ POLITYKI RODZINNEJ ZORIENTOWANEJ NA RODZINIE FUNKCJONALNEJ}

\section{Streszczenie}

Wprowadzenie. Współczesne tendencje rozwoju rodziny na Ukrainie rozpatrywane są w kontekście państwowej polityki rodzinnej.

Celem artykułu jest analiza tendencji rozwoju współczesnej rodziny na Ukrainie oraz znalezienie sposobów jej wsparcia na poziomie kształtowania państwowej polityki rodzinnej.

Wyniki. Na podstawie analizy danych statystycznych, badań naukowych jest analizowana specyfika rodzin ukraińskich, w szczególności kryzysowe przejawy ich funkcjonowania (wysoki poziom rozwodów, spadek dzietności, wzrost popularności alternatywnych form związków roś dzinnych). Analizowane są dane dotyczące przejawów negatywnych zjawisk społecznych, które są konsekwencjami dysfunkcji rodziny - nieodpowiedzialne rodzicielstwo, przemoc w rodzinie, sieroctwo społeczne, przestępczość nieletnich. Można stwierdzić, że państwowa polityka rodzinna, koncentrując się na pracy z rodzinami dysfunkcyjnymi, w rzeczywistości nie zapewnia wsparcia rodzinom bez tych problemów.

Wnioski. Podkreśla się konieczność stworzenia zintegrowanej (całościowej) polityki rodzinnej skierowanej na rozwój rodziny i wspieranie prawidłowo funkcjonujących rodzin, co będzie sprzyjało realizacji systematycznej, spójnej pracy w głównych kierunkach: tworzenie wartości rodzinnych priorytetowych w społeczeństwie; przygotowanie dzieci i młodzieży do tworzenia rodziny, rozwój odpowiedzialnego rodzicielstwa; zapobieganie dysfunkcjom rodziny; pomoc rodzicom wychowującym dzieci; wsparcie społeczne dla rodzin w trudnych warunkach życia.

Słowa kluczowe: rodzina; polityka rodzinna; rodzina dysfunkcyjna; rodzina funkcjonująca prawidłowo; funkcje rodziny. 